\title{
Smoke, alcohol and drug addiction and male fertility
}

\author{
Andrea Sansone ${ }^{1 *}$ (D), Carla Di Dato ${ }^{1}$, Cristina de Angelis ${ }^{2,3}$, Davide Menafra $^{3}$, Carlotta Pozza ${ }^{1}$, Rosario Pivonello $^{3}$, \\ Andrea Isidori ${ }^{1}$ and Daniele Gianfrilli ${ }^{1}$
}

\begin{abstract}
In recent decades, the decline in human fertility has become increasingly more worrying: while therapeutic interventions might help, they are vexing for the couple and often burdened with high failure rates and costs. Prevention is the most successful approach to fertility disorders in males and females alike. We performed a literature review on three of the most common unhealthy habits - tobacco, alcohol and drug addiction - and their reported effects on male fertility. Tobacco smoking is remarkably common in most first-world countries; despite a progressive decline in the US, recent reports suggest a prevalence of more than $30 \%$ in subjects of reproductive age - a disturbing perspective, given the well-known ill-effects on reproductive and sexual function as well as general health. Alcohol consumption is often considered socially acceptable, but its negative effects on gonadal function have been consistently reported in the last 30 years. Several studies have reported a variety of negative effects on male fertility following drug abuse - a worrying phenomenon, as illicit drug consumption is on the rise, most notably in younger subjects. While evidence in these regards is still far from solid, mostly as a result of several confounding factors, it is safe to assume that cessation of tobacco smoking, alcohol consumption and recreational drug addiction might represent the best course of action for any couple trying to achieve pregnancy.
\end{abstract}

\section{Background}

Almost $15 \%$ of all couples trying to conceive are affected by infertility, and in almost half of these cases male infertility is the sole or a contributing factor [1]. The decline of male fertility is not an empty threat: evidence points at a steadily progressive decline of sperm concentration over the past 35 years [2]. These reports have rekindled the interest in the potential impact of environmental factors and lifestyle on fertility: in order to decrease the social costs of male infertility and the resulting burdens on public health, identifying preventable factors is of the utmost importance. Sedentary behavior and obesity have both been associated with impaired male fertility $[3,4]$ and have often been addressed as potentially preventable factors; a more detailed review on the effects of sports and physical activity on male fertility is included in this Special Issue. The role of other unhealthy lifestyles, such as smoking

\footnotetext{
* Correspondence: andrea.sansone@uniroma1.it

${ }^{1}$ Department of Experimental Medicine, Section of Medical Pathophysiology, Food Science and Endocrinology, Sapienza - University of Rome, Viale Regina Elena 324, 00161 Rome, Italy

Full list of author information is available at the end of the article
}

and alcohol consumption, and environmental stressors on general health is universally recognized, but their effects on male fertility are less known [5]. Indeed, male reproductive health may be a sensitive marker of pollution [6] and environmental exposures [7, 8]. For ethical reasons, interventional studies in regards to the effects of tobacco use, second-hand smoking, recreational drug abuse and alcohol consumption are generally not feasible in humans. The vast majority of studies on these topics are therefore retrospective [8]. Sadly, this leads to a wide array of confounders, for which control is limited. A partial solution comes from animal studies; however, exposure in these models is significantly higher than in humans, and as such results should be interpreted with caution.

In order to provide an up-to-date and reliable reference in regards to the possible role of alcohol, tobacco and recreational drugs on male fertility, we performed a thorough review of existing literature and gathered all necessary data. 


\section{Causes of male infertility}

Couple infertility is defined by the failure to achieve pregnancy after at least 12 months of regular, unprotected intercourse. On the other hand, providing a fitting definition for male infertility is a more difficult task: diagnosis is traditionally based on semen analysis results, compared to the World Health Organization reference values [9].

Successful spermatogenesis is the result of the complex interaction between endocrine, paracrine and autocrine factors [10]. Unsurprisingly, several acquired and congenital conditions might impair the fine mechanisms involved in spermatogenesis (Table 1). Acquired testicular failure, as often observed following testicular torsion, orchitis, or administration of cytotoxic treatment is often associated with azoospermia. Varicocele, testicular trauma, and medications might affect fertility, although in most circumstances the spermatogenesis is impaired to a lesser extent. Genetic abnormalities, such as Klinefelter Syndrome or microdeletions in the AZF (azoospermia factor) region on the human male Y chromosome, usually manifest with azoospermia; however, small nucleotide polymorphisms are being investigated as a possible cause of "idiopathic" oligo-azoospermia. However, despite the recent discoveries in regards to the genetics of male infertility, to the present date most causes of oligozoospermia remain unknown.

Age is significantly associated with decline in semen quality, supposedly as a result of continued replications

Table 1 Possible acquired causes of male reproductive impairment

Hypothalamic-pituitary axis
Compressive effect (Pituitary or brain tumors)
Ablative effect (CNS surgery or radiotherapy)
Infiltrative effect (fungal infections, sarcoidosis, hemochromatosis)
Suppressive effect (exogenous AAS)
Quantitative alterations of spermatogenesis
Varicocele
Previous chemotherapy or radiotherapy
Testicular failure (torsion, orchitis, orchiectomy)
Comorbidities (liver and kidney disease)
Qualitative alterations of spermatogenesis
Oxidative stress
DNA damage
Ductal obstructions
Surgery (vasectomy, hernia repair, pelvic surgery)
Neurological disorders (Multiple Sclerosis, Spinal Cord Injury, neural
tube defects)
Erectile or ejaculatory dysfunction

Abbreviations: CNS central nervous system, AAS anabolic-androgenic steroid. Edited from $\mathrm{H}$ Tournaye, C Krausz and RD Oates [10] from mutated spermatogonial stem cells [11]. DNA fragmentation and chromatin condensation might also play a role in the pathogenesis of male infertility [12]. Among non-genetic causes of male infertility, oxidative stress resulting from exaggerated production of reactive oxygen species (ROS) is perhaps the most known factor. ROS are needed for capacitation, the acrosome reaction and ultimately fertilization; however, reduced clearance and excessive production are both able to induce DNA damage and defective membrane integrity in sperm cells, therefore resulting in reduced fertility potential [13]. Semen from fertile men has a more effective antioxidant capacity than that from infertile men; furthermore, immature teratozoospermic forms produce relatively more ROS than normal, mature sperm [13]. Inflammatory processes and vascular diseases, including varicocele, can supposedly increase ROS production: a thorough evaluation aimed to assess the presence of predisposing conditions is mandatory in the evaluation of any infertile male.

\section{Tobacco smoking and male fertility}

More than $60 \%$ of noncommunicable diseases list smoking among their risk factors, and every year more than six million deaths result from tobacco consumption and second-hand smoke [14]. Despite the growing body of evidence supporting its deleterious effects, smoking is still a widespread phenomenon, as proven by recent reports from the World Health Organization. More than one-third of all male adults worldwide use tobacco [15]; similarly, approximately $30 \%$ of women of reproductive age smoke cigarettes [16]. Europe is still the leading continent in regards to tobacco use, whereas smoking rates have gradually declined in the United States in recent years [17].

\section{Clinical studies}

The deleterious effects of smoking on fertility have been described since 1983: Olsen and colleagues identified tobacco use as one of the causes of otherwise unexplained infertility in more than 1000 females [18]. To the present date, more than 4700 different chemicals have been identified in tobacco smoke [19], ranging from heavy metals to polycyclic aromatic hydrocarbons to mutagenic chemicals. A significant association between seminal plasma lead levels and lifetime smoking estimate has been reported [20]; likewise, smoking is considered the most common source of lead and cadmium exposure [21]. Some metal micronutrients involved in the pathogenesis of oxidative stress and male infertility, including arsenic and the aforementioned cadmium and lead, are routinely inhaled during combustion of tobacco or cigarette paper [21]. These metals all have mutagenic properties and are similarly associated with increased 
risk of male infertility, despite no significant differences in semen volume, concentration, and motility [22, 23]. On the other hand, impairments in sperm parameters have been observed in many studies in the last decades $[24,25]$ : in most of them, alterations in morphology and decreased concentration, motility and viability have been observed among smokers. A significant decrease in sperm concentrations of current smokers compared with those who had never smoked has been observed in a meta-analysis of more than 2500 men from five separate studies [26]. Similarly, Kunzle and colleagues have found a significant association between smoking and reduced sperm concentration in 2100 men presenting for fertility evaluation [27].

Mechanisms resulting in impaired sperm parameters have been investigated, but definite evidence is still missing. Ultra-structural abnormalities, mostly affecting axonemal microtubules and tail alterations, have been reported in heavy smokers [28, 29]; similarly, smoking impairs the acrosome reaction [30] and capacitation [31], two processes ultimately needed for fertilization. Increased oxidative stress has been suggested as a possible mechanism resulting in impaired sperm functions. Hypoxia resulting from cigarette smoking might also be responsible for impaired spermatogenesis, even more dramatically in patients with varicocele [8, 32]. Mitochondrial activity and chromatin structure in human sperm might be impaired by several toxins, therefore negatively affecting fertilization capacity both in vivo and in vitro $[17,33,34]$.

Hypothetically, chronic cigarette smoking increases liver metabolism of testosterone, while at the same time inducing secretory dysfunction of Leydig and Sertoli cells [24]. However, there seems to be no general consensus on the effects of smoking on FSH and $\mathrm{LH}$ production: some studies have shown lower levels of both gonadotropins among smokers, whereas different researchers have observed increased concentration of $\mathrm{LH}$ and/or FSH following tobacco consumption [35, 36]. Considering all the possible confounding factors, testosterone concentration is remarkably difficult to ascertain among smokers: some studies have reported increased serum testosterone and dehydroepiandrosterone levels in smokers [35, 37], whereas others have suggested that mean levels of testosterone are not significantly different [38] between smokers and non-smokers.

The American Society of Reproductive Medicine in 2012 stated that "semen parameters and results of sperm function tests are $22 \%$ poorer in smokers than in nonsmokers and the effects are dose-dependent" [16]. More recently, a meta-analysis study on a grand total of 5865 subjects has concluded that moderate and heavy smokers are more likely to have reduced sperm count and motility [17]. Evidence suggests a significant role for cigarette smoking on spermatogenesis, but on the other hand the impact of smoking on male fertility has yet to be fully elucidated. A preventive approach to infertility, suggesting smoking cessation and reduction of secondhand smoking in both women and men, should be suggested.

\section{Experimental studies \\ Animal studies}

Cigarette smoking results in accumulation of benzo(a)pyrene $(\mathrm{B}[\mathrm{a}] \mathrm{P})$ and cotinine, ultimately leading to DNA damage and testicular cytotoxicity in rodent models. In a recent study, Esakky and colleagues [39] reported significantly decreased expression of aryl hydrocarbon receptor $(A h r)$, and enhanced expression of Fas, FasL, BCL2, and activated caspase-3 proteins in testes exposed to cigarette smoke condensate. The reduced expression of Ahr increases susceptibility of germ cells to polycyclic aromatic hydrocarbons, while the remaining proteins all induce apoptosis via extrinsic (FAS, FASL) or mitochondrial processes (BCL, caspase-3). Tobacco use is also closely associated to reduced antioxidant activity, therefore worsening the effects of oxidative stress [40].

Exposure to cigarette smoke also impairs the activity of sorbitol dehydrogenase and lactate dehydrogenase, reflecting the effects on spermatogenesis and sperm maturation in rats [41]. Most importantly, histomorphological alterations of testes, significantly increased abnormalities in epidydimal spermatozoa and sperm DNA damage have been observed in rats exposed to cigarette smoke $[41,42]$. In both in vitro and in vivo studies, nicotine resulted involved in direct impairment of sperm motility and in apoptosis induction in rat Leydig cells [43]. Mice exposed to cigarette smoke also underwent alterations in cell signal pathway networks, including ERK1/2, nuclear factor- $\mathrm{kB}$ and several protein kinases involved in spermatogenesis; furthermore, modified DNA methylation patterns were observed near transcriptional start sites for the PEBP1 gene. Expression of PEBP1 results in production of phosphatidylethanolamine-binding protein 1 , a protein that in humans has been shown to interact with C-Raf, MAP2K1 and MAPK1 [44].

High doses of nicotine induce a significant decrease in sperm count and motility in prepubertal and adult rats exposed to progressively increasing concentrations of nicotine [45]. Impaired testicular function is also reflected in significantly decreased testosterone levels $[45,46]$, although as previously suggested it's still unclear whether these findings are valid for humans as well as rodents.

Smoking cessation, on the other hand, improves indices of sexual health for long-term male smokers [47] and, based on finding in animal models, might improve 
sperm parameters [48]. However, to the present date, no conclusive evidence on the real improvements in male fertility following smoking cessation has been obtained.

\section{Studies in humans}

Recent genome-wide studies have identified alterations in the methylation profile of 95 sites in smokers [49]. Smoking-related DNA damage and methylation patterns are observed in several human tissues - even those who are not directly exposed to it because of indirect systemic exposure [50]. DNA adducts and DNA damage are inversely associated with sperm parameters, mostly concentration and motility, and both are transmitted to the zygote with little chance of repair by the ovum [51]. Sperm DNA fragmentation is also linked with increased rates of spontaneous abortion [52] and should therefore be carefully assessed in subjects undergoing assisted reproduction techniques. Oxidative DNA damage [53] and higher cadmium levels [54] resulting from tobacco consumption are similarly associated to impaired fertility, resulting in longer time to pregnancy for couples.

Smoking also reduces sperm creatine kinase activity, therefore impairing sperm motility and energy homeostasis [55]. In vitro studies have shown nicotine, cotinine and cadmium as possible culprits; in vivo, both smoking duration and amount of cigarettes smoked per day seem able to reduce creatine kinase activity in sperm $[56,57]$.

\section{Alcohol consumption and male fertility}

Clinical and experimental studies have examined alcohol consumption as a potential risk factor for male infertility, exerting a direct effect on both testosterone metabolism and spermatogenesis.

\section{Clinical studies}

The link between alcohol and fertility was investigated in 1985 for the first time. The analysis of seminal fluid samples and the hormonal evaluation of 20 men with alcohol dependence syndrome revealed a significant decrease in testosterone levels, seminal fluid volume and sperm concentration in chronic alcoholics than in controls [58]. Subsequently, a prospective autopsy study showed that a significant percentage of heavy drinkers (52.3\%) had partial or complete spermatogenic arrest, and that the mean testicular weight of heavy drinkers was slightly but significantly lower compared with that of controls [59]. Muthusami et al., in 2005, found in chronic alcoholics a significant increase of FSH, LH, and E2 levels, while testosterone was significantly decreased. Semen volume, sperm count, motility, and number of morphologically normal sperm were significantly decreased [60]. In 2011 one meta-analysis including 57 studies and 29,914 subjects found a significant association between alcohol, semen volume, sperm morphology and sperm motility [61].

Therefore, chronic and excessive alcohol intake seem to have a detrimental effect on male reproductive hormones and on semen quality. Conversely, the effect of moderate alcohol intake is still under debate.

A cross sectional study from Jensen et al. on 8344 healthy men suggest that moderate alcohol intake (median weekly intake 8 units) is not adversely associated with semen quality in healthy men, whereas it was associated with higher serum testosterone levels [62]. Furthermore, chronic alcohol consumption seem to influence fertility more than acute alcohol consumption. Hansen et al. evaluated the association between last 5 days of alcohol intake, semen quality and reproductive hormones in a cross-sectional study among 347 men [63]. Alcohol intake was associated with impairment of most semen characteristics but without a coherent dose-response pattern. There was a tendency towards lower semen characteristics at higher intake of alcohol past 5 days and a hormonal shift towards higher estradiol/testosterone ratio. The importance of the timing of alcohol consumption was also established from Condorelli et al. The Authors retrospectively evaluated semen and hormonal parameters of moderate alcohol users, comparing occasional drinkers with daily drinkers. Within each group, a further comparison was made between the fertile subjects (pregnancy over the past 12 months) and the infertile patients (no evidence of pregnancy or fertilisation for at least 12 months). The results showed that infertile patients belonging to group of 'daily drinkers' have a semen quality and hormonal characteristics significantly worse compared with the other groups [64]. Time-topregnancy for was significantly longer in couples in which the male partner consumed more than 20 units of alcohol on a weekly basis [65], but literature is severely lacking concerning more moderate consumption of alcoholic beverages.

The mechanisms underlying the damage of alcohol on fertility are not yet fully clarified. Close and colleagues reported that current heavy alcohol users have significantly higher leukocyte concentrations in the seminal fluid compared with nonusers. After controlling for past sexually transmitted diseases and multiple substance exposures in a multivariate model, alcohol users had only a trend towards increased leukocytes in the seminal fluid [66]. Some Authors hypothesized that also maternal alcohol consumption during pregnancy can influence semen quality in the male offspring. From a cohort of Danish pregnant women established in 1984-1987, 347 young adult sons were selected for a follow-up study conducted in 2005-2006. The results of this study showed that the sperm concentration decreased with increasing prenatal alcohol exposure. No associations were 
found for sperm motility, sperm morphology, or any of the reproductive hormones, including testosterone [67].

\section{Experimental studies \\ Animal studies}

Alcohol consumption has often been associated with an increase in $\beta$-endorphin levels that could be involved in testicular damage, inducing sperm apoptosis. In 1999 Yin and colleagues showed that morphine induces the expression of the protein Fas (also known as CD95 or APO-1), a receptor on the cell surface that triggers the cell's suicide by apoptosis when it binds to its ligand, FasL [68]. Furthermore, an experimental study demonstrated that treatment with naloxone and naltrexone in adult and pubertal male rats could prevent alcoholinduced testosterone inhibition [69].

Apoptosis is one of the responsible factors for spermatozoal chromatin disorders. Several studies showed that ethanol consumption disturb nuclear maturity and DNA integrity of spermatozoa. Talebi and colleagues evaluated the effect of ethanol consumption on sperm parameters and chromatin integrity of spermatozoa aspirated from cauda epididymis of rats. Results revealed that sperm progressive and non progressive motility of ethanolconsuming rats were significantly decreased compared with control animals and an alteration of nuclear maturity and DNA integrity [70].

Therefore, spermatogenic cells undergo apoptosis when treated with ethanol but the mechanism remain unclear. In the study of Jana and colleagues, intraperitoneal injection of ethanol induced apoptotic spermatogenic cell death with a decrease in the plasma and intra-testicular testosterone in adult male mice. In this study, western blot analysis revealed that repeated ethanol treatment decreased the expression of steroidogenic acute regulatory protein (StAR), 3b-hydroxysteroid dehydrogenase (3b-HSD) and 17b-hydroxysteroid dehydrogenase (17b-HSD); increased the expression of active caspase-3, p53, Fas and Fas-L; and led to up-regulation of $\mathrm{Bax} / \mathrm{Bcl}-2$ ratio and translocation of cytochrome $\mathrm{c}$ from mitochondria to cytosol in testis. Moreover, repeated ethanol treatment led to upregulation of caspase3, p53, Fas and Fas-L transcripts; increase in caspase-3 and caspase-8 activities; diminution of 3b-HSD, 17b-HSD and GPx activities; decrease in the mitochondrial membrane potential along with ROS generation and depletion of glutathione pool in the testicular tissue [71].

\section{Studies in humans}

Polycyclic aromatic hydrocarbons (PAH) are ubiquitous pollutants in the environment, which are able to form DNA adducts when they are activated to DNA reactive metabolites. Measurement of DNA adducts is a widely used marker of DNA damage induced by environmental pollutants. Gaspari and colleagues evaluated data on (PAH)-DNA adducts in 182 men with morphological abnormalities in the sperm, finding a significant negative association was between daily alcohol consumption and PAH-DNA adducts in sperm [72]; similarly, Rossi and colleagues reported that increased alcohol consumption was associated with fertilization failure and reduced live birth rates [73], with a $21 \%$ decline in couples in which both partners drank more than 4 units per week. On the contrary, in the study of Horak et al., no correlation between alcohol and sperm DNA adducts was found [74]. Finally, Loft evaluated the level of oxidative DNA damage in terms of 7-hydro-8-oxo-20-deoxyguanosine (8-oxodG) in sperm DNA among 225 first-pregnancy planners and the 8-oxodG level was not significantly associated with consumption of alcohol [53].

Finally, the genetic background may modulate the impact of alcohol on spermatogenesis. The glutathione S-transferase (GST)-M1 genotype may be associated with a greater susceptibility to develop, via direct mechanism at testicular level, alcohol-induced spermatogenesis disorders. An autopsy study comprising 271 subjects showed that among 50 moderate drinking men, $48 \%$ had partial and 10\% complete spermatogenic arrest. Among the 21 men with normal spermatogenesis, $42.9 \%$ had GST M1 genotype with a frequency similar to that found in men with partial or complete spermatogenic arrest (44.8\%). Among the 212 heavy-drinking men, $21.2 \%$ of the subjects had normal spermatogenesis, $36.3 \%$ had partial spermatogenic arrest, $38.2 \%$ showed complete arrest spermatogenic arrest and $4.2 \%$ showed Sertoli cellonly syndrome. Interestingly, 27 of the 45 heavy drinkers with normal spermatogenesis $(60 \%)$ men had the GST M1 genotype. The finding that $>20 \%$ of heavy drinkers had normal spermatogenesis suggests that the GST M1 genotype exerts a protective effects on alcohol-induced spermatogenesis disorders [75].

\section{Drugs addiction and male fertility}

Up to almost one in four men under the age of 35 years uses recreational drugs [76]. Several studies have suggested that these drugs might have adverse effects on human reproduction. Cannabis smoking has been shown to negatively impact male fertility, with an effect on hypothalamus-pituitary-gonadal axis, spermatogenesis, and sperm function, as cannabinoid receptors are expressed in the anterior pituitary, Leydig cells, Sertoli cells and in testicular tissues [77]. Similarly, negative effects on male fertility have been reported in subjects using cocaine, MDMA (ecstasy) and opioids. Cocaine use has been associated with other high-risk behaviors, such as tobacco smoking and sexually transmitted 
diseases, and might lead to testicular cell apoptosis; opioids act on the HPG axis, possibly resulting in hypogonadal hypogonadism; DNA damage and tubular degeneration have been described in rats treated with MDMA. Prevention of male infertility might be achieved by identifying and addressing the consequences of the "illicit drug epidemic".

\section{Clinical studies}

In literature, human data on hormone levels following marijuana exposure are conflicting. Referring to animal studies it could be possible that consuming cannabis decrease serum luteinizing hormone and testosterone levels, but in clinical studies a univocal interpretation is lacking.

A study from Kolodny et al. on 20 men who used marijuana chronically showed significantly lower levels of plasma testosterone in this group than that in the control-group. Decreased testosterone was dose related. Abstention from marijuana use or stimulation with human chorionic gonadotropin during continued marihuana use produced marked increases in testosterone [78]. These results have been later contradicted. In 66 males neither chronic nor acute intake of marijuana had a significant effect on plasma testosterone levels, but also subjects who drank cannabis as a tea were included [79]. In a study of 27 men, no statistically significant changes in plasma testosterone levels were observed during and after the smoking period as compared with the pre-smoking base-line levels [80]. In four healthy males subjects, cannabis smoking significantly depressed plasma LH, while cortisol significantly increased [81]. On the contrary, in the study from Gundersen et al. on 1215 Danish healthy young men, of whom $45 \%$ had smoked marijuana during the past 3 months, marijuana use was associated with increased serum testosterone to the same level as cigarette smoking [82].

Conversely, regarding the effect of cannabis on spermatogenesis, clinical studies showed an effect on volume, number morphology, motility, and fertilization capacity.

In the study from Gundersen et al. regular use of marijuana was found to be associated with an impairment in semen quality, while irregular use seems to be irrelevant [82]. A study from Hembree et al. showed an association between marijuana use and decreased sperm count, which persisted in the following 4-week recovery period [83]. These data were confirmed also by a case study on a multidrug addict, in which semen abnormalities were detected before and 2 years after cessation of the abuse [84]. In a recent unmatched case-referent study with 1700 participants, it was clearly reported that cannabis exposure is a risk factor for poor sperm morphology [85]. Only one study on 159 men attending an infertility clinic demonstrated a positive correlation between marijuana use and percentage of motile sperm [66].

There are no studies on the effect of cannabis on the reproductive organs of men. Only Kolodny et al. reported no change in testicular size and texture in chronic marijuana users [78]. The differing results of these reports may in part be due to study design, the ingestion of other pharmacological agents, such as narcotics, alcohol and cigarette smoking.

Cocaine intake during pregnancy severely affects fetal development; however, little is known in regards to its effects on male fertility. The same applies to MDMA (Ecstasy): animal models might help understand the specific effects of both substances on male fertility. Bracken et al. [86] reported increased use of cocaine among subjects with lower sperm counts and motility; Samplaski et al. [87] more recently suggested that the higher rates of concurrent substance abuse, tobacco use and infections among cocaine users might lead to biased results.

Opioids act on the hypothalamic-pituitary axis by inhibiting the pulsatility of $\mathrm{GnRH}$ secretion: the resulting suppression of FSH and $\mathrm{LH}$ release consequently leads to impaired spermatogenesis and reduced testosterone concentrations [76]. Vuong et al. [88] performed a lengthy review of the effects of opioids on endocrine parameters, and concluded that there is still insufficient information on the long-term effects of opioids in regards to fertility despite concrete evidence of opioid-induced hypogonadism. Recent reports suggest that both sperm concentration and quality are impaired in opioid abusers: increased rates of DNA fragmentation and reduced expression of catalase-like and superoxide dismutase-like activity were observed in addict men compared to age-matched healthy volunteers [89].

\section{Experimental studies Animal studies}

Acute treatments with cannabinoids can decrease the fertilising capacity of sea urchin sperm [90]. In rodent studies, high THC doses caused a modest increase in abnormally formed sperm. Moreover, long-term cannabinoid exposure in male mice disrupted spermatogenesis and induced aberrations in sperm morphology [91].

Wenger and colleagues showed that THC alters pituitary $\mathrm{LH}$ release by inhibiting the release of $\mathrm{LHRH}$, injecting THC into the third cerebral ventricle of male rats [92]. Smith et al. [93] found a significant decrease in serum testosterone concentration following acute doses of THC in rhesus monkeys. A study on adult male mice showed regressive changes in the testes and suppressed sperm count, viability and motility, caused by chronic intake of bhang. Bhang intake also caused significant 
Table 2 Effects of tobacco smoking, alcohol consumption and drug addiction on spermatogenesis and sperm parameters

\begin{tabular}{|c|c|c|}
\hline & Studies in humans & Animal studies \\
\hline $\begin{array}{l}\text { Tobacco } \\
\text { smoking }\end{array}$ & $\begin{array}{l}\text { Reduction of sperm concentration }[26,27] \\
\text { Impairment of sperm motility [17] } \\
\text { Increase in ultra-structural abnormalities (axonemal } \\
\text { microtubules and tail alterations) }[28,29] \\
\text { Impairment of mitochondrial activity and chromatin structure }[17,33,34] \\
\text { Impairment of acrosome reaction and capacitation }[30,31] \\
\text { Increase of DNA methylation patterns }[49] \\
\text { Alterations in ERK1/2, nuclear factor-KB signal pathway [44] } \\
\text { Reduction of creatine kinase activity in sperm [55-57] }\end{array}$ & $\begin{array}{l}\text { Increase in apoptosis via extrinsic (FAS, FASL) or } \\
\text { mitochondrial processes (BCL, caspase-3) in rats }[39,40] \\
\text { Reduction of antioxidant activity in rats }[40] \\
\text { Increase in DNA damage in sperm rats }[41,42] \text {; of DNA } \\
\text { methylation patterns PEBP1 gene in rats }[44] \\
\text { Reduction of sperm count and motility in rats [45] }\end{array}$ \\
\hline $\begin{array}{l}\text { Alcohol } \\
\text { consumption }\end{array}$ & $\begin{array}{l}\text { Reduction of seminal volume and sperm concentration }[58,61,62] \\
\text { Impairment of sperm motility and morphology }[60,61] \\
\text { Increased sperm polycyclic aromatic hydrocarbon DNA adducts [72] }\end{array}$ & $\begin{array}{l}\text { Increase in apoptosis (by upregulation of Fas) of } \\
\text { spermatogenic cells in rats [68] } \\
\text { Alteration of nuclear maturity and DNA integrity in } \\
\text { sperm cells of rats [70] } \\
\text { Increase in ROS generation and depletion of } \\
\text { glutathione pool in testicular tissue of rats [71] } \\
\text { Impairment of sperm motility in rats [70] }\end{array}$ \\
\hline \multicolumn{3}{|l|}{ Drug addiction } \\
\hline Marijuana & $\begin{array}{l}\text { Decrease in sperm count }[82-84] \\
\text { Impairment of sperm morphology and motility }[85,102,103] \\
\text { Reduction of spontaneous acrosome reactions }[102,103]\end{array}$ & $\begin{array}{l}\text { Impaired sperm concentration and morphology in rats } \\
\text { [91] } \\
\text { Inhibition of sperm ATP production in rats [104] } \\
\text { Reduction of fructose and citric acid contents in testis } \\
\text { and prostate of male rats [95] }\end{array}$ \\
\hline Cocaine & Impairment of sperm counts and motility [86] & $\begin{array}{l}\text { Vasoconstriction of testicular blood vessels in rats } \\
\text { resulting in ischemic and reperfusion injuries [96] } \\
\text { Reduction of diameter of seminiferous tubules [97] } \\
\text { Decrease in number of total germ cells [97] } \\
\text { Increase in oxidative stress in mice [98] }\end{array}$ \\
\hline Opioids & $\begin{array}{l}\text { Impaired spermatogenesis [76] } \\
\text { Increased rates of DNA fragmentation in humans [89] } \\
\text { Reduced expression of catalase-like and superoxide } \\
\text { dismutase-like activity [89] }\end{array}$ & $\begin{array}{l}\text { Increase of rates of DNA damage and tubular } \\
\text { degeneration in rats }[100,101]\end{array}$ \\
\hline $\begin{array}{l}\text { Amphetamines } \\
\text { and Ecstasy }\end{array}$ & No data available & $\begin{array}{l}\text { Vasoconstriction of testicular blood vessels in rats [96] } \\
\text { Increase in rates of DNA damage and tubular } \\
\text { degeneration in rats [99] }\end{array}$ \\
\hline
\end{tabular}

Table 3 Effects of tobacco smoking, alcohol consumption and drug addiction on hormone levels

\begin{tabular}{|c|c|c|}
\hline & Studies in humans & Animal studies \\
\hline Tobacco smoking & $\begin{array}{l}\text { Increase in liver metabolism of testosterone [24] } \\
\text { Reduction of LH and/or FSH levels [34] } \\
\text { Increase in concentration of LH and/or FSH [35] } \\
\text { Increase in serum testosterone and DHEA levels [35, 37] }\end{array}$ & Reduction of testosterone levels in rats $[45,46]$ \\
\hline $\begin{array}{l}\text { Alcohol } \\
\text { consumption }\end{array}$ & $\begin{array}{l}\text { Decrease in testosterone levels }[58,59] \\
\text { Increase in FSH, LH, and E2 levels }[60]\end{array}$ & $\begin{array}{l}\text { Decrease in plasma and intra-testicular testosterone in } \\
\text { rats [71] }\end{array}$ \\
\hline \multicolumn{3}{|l|}{ Drug addiction } \\
\hline Marijuana & $\begin{array}{l}\text { Decrease in levels of plasma testosterone [78] } \\
\text { Decreased levels of plasma LH, and increased levels of plasma cortisol } \\
\text { [81] } \\
\text { Increased serum testosterone [82] }\end{array}$ & $\begin{array}{l}\text { Inhibition of LHRH release in rats [92] } \\
\text { Decrease in testosterone levels in monkeys [93] }\end{array}$ \\
\hline Cocaine & $\begin{array}{l}\text { Increase in LH levels without modifying testosterone following acute } \\
\text { administration [97] }\end{array}$ & $\begin{array}{l}\text { Increase in LH levels; No effects on testosterone and } \\
\text { estradiol in rats [97] }\end{array}$ \\
\hline Opioids & $\begin{array}{l}\text { Inhibition of the pulsatility of GnRH secretion; reduction of LH, FSH and } \\
\text { testosterone levels [76] }\end{array}$ & $\begin{array}{l}\text { Reduction of } \mathrm{LH} \text {, without effect on FSH and testosterone } \\
\text { levels in rats [101] }\end{array}$ \\
\hline $\begin{array}{l}\text { Amphetamines } \\
\text { and Ecstasy }\end{array}$ & No data available & $\begin{array}{l}\text { No effects on LH, FSH, Testosterone levels in male rats } \\
\text { [99] }\end{array}$ \\
\hline
\end{tabular}


decline in circulating testosterone level due to decline in testicular 3b HSD enzyme activity, a significant variation in the CB1 and CB2 receptors and FAAH protein levels (Fatty Acid Amide Hydrolase) in testes of mice exposed to bhang [94]. Finally, repeated subcutaneous administration of cannabis extract and delta-9-tetrahydrocannabinol reduced significantly fructose and citric acid contents of male reproductive organs of prepubertal as well as adult albino rats in a dose-related manner in the testis, prostate as well as in the epididymis [95].

Effects of cocaine and MDMA on fertility have been evaluated in animal models: in rodents, cocaine is able to induce prolonged vasoconstriction of testicular blood vessels, resulting in ischemic and reperfusion injuries [96]. In 1996, George et al. reported that in rats long-term exposure to cocaine resulted in reduced diameter of seminiferous tubules and similarly decreased number of total germ cells [97]. More recently, increased oxidative stress has been observed in mice following chronic administration of cocaine [98], suggesting a possible mechanism for testicular damage. Similar findings have been reported for Ecstasy and opioids: Barenys et al. described significantly decreased sperm concentration and motility, together with increased rates of DNA damage and tubular degeneration, in rats treated with varying dosages of MDMA [99], and similar findings have been described in mice treated with either tramadol [100] or morphine [101].

\section{Studies in humans}

Whan et al. investigated the effects of delta-9tetrahydrocannabinol (THC) on human sperm function in vitro. Both therapeutic and recreational levels of THC determined a dose dependent reduction of sperm motility and of spontaneous acrosome reactions [102]. Subsequent studies confirmed these results [103], but the mechanism still remained not fully understood. Morgan et al. investigated the effects of WIN 55,212-2, a CB1 cannabinoid receptor agonist, and D9-tetrahydracannabinol (D9-THC) on the ATP levels and motility of murine sperm in vitro. High concentrations of WIN 55,212-2 or D9-THC inhibit ATP production in sperm; this effect of WIN 55,212-2 is CB1 receptor dependent whereas that of D9-THC is not [104].

\section{Conclusions}

Despite the lack of solid evidence from interventional studies, which are for the most part not feasible in humans, it is clear that smoking, alcohol use and recreational drug consumption are somehow able to impair male fertility, with possible synergistic, rather than addictive, effects. Impairments in spermatogenesis and sperm parameters as well as increased DNA methylation and oxidative stress have been observed in humans and animal models alike; similarly, effects on endocrine control of reproductive and sexual function have been reported in clinical and

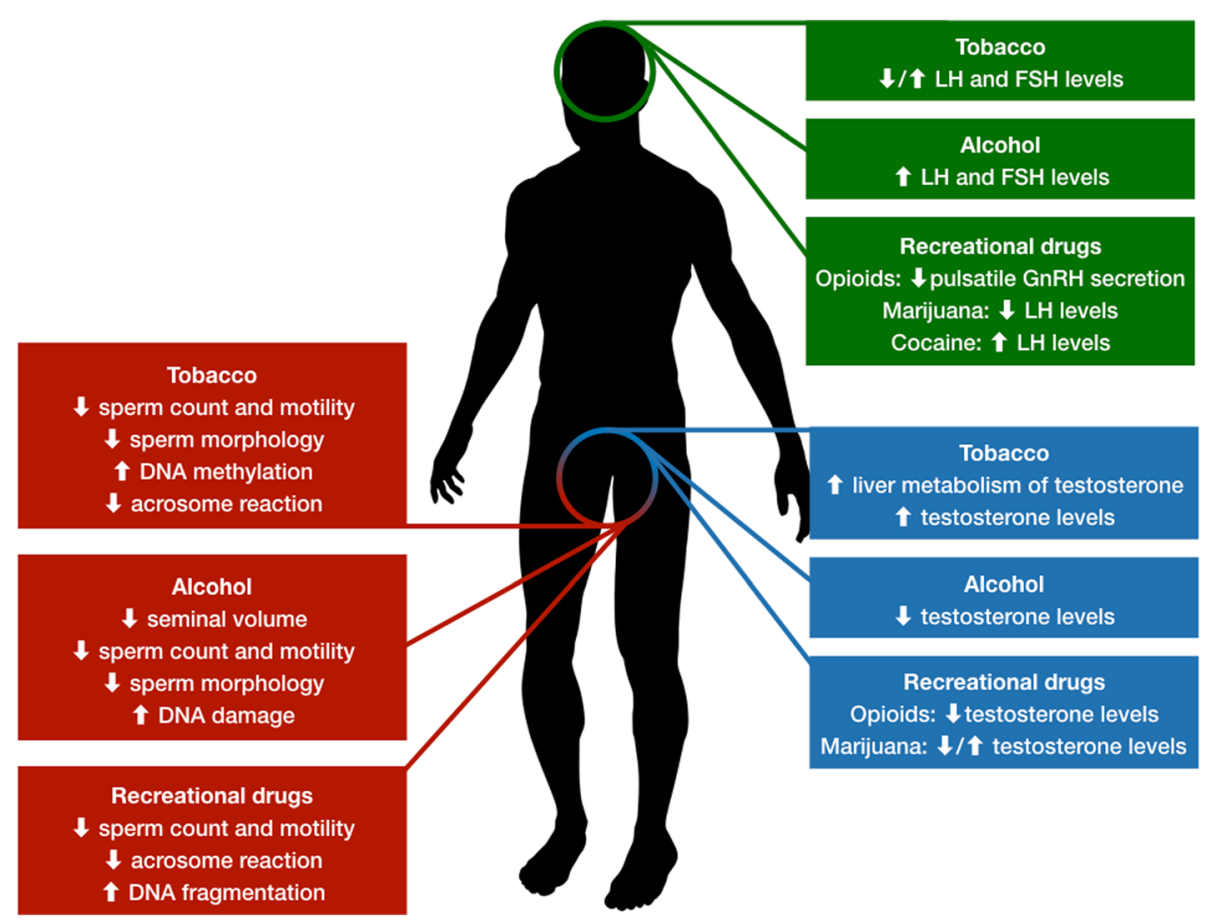

Fig. 1 Effects of smoking, alcohol and drug abuse on spermatogenesis (left) and hormonal parameters (right) in males 
experimental studies (Tables 2 and 3, Fig. 1). Discontinuation of all these habits should be suggested in all patients undergoing investigation for infertility in order to provide the best outcomes, although little is known in regards to the time needed for cessation of negative effects.

\section{Acknowledgements}

None

\section{Funding}

No funding was requested for this review.

\section{Availability of data and materials}

Literature research results are available from the authors on reasonable request.

\section{Declarations}

Since Prof. Pivonello served as Guest Editor of the thematic series "The Influence of Environment and Lifestyle on Human Fertility", peer review of the present manuscript was handled by another member of the Reproductive Biology and Endocrinology editorial board.

\section{Authors' contributions}

AMI and DG conceived the idea. AS and CdD were involved in literature collection. All authors independently and critically reviewed the selected manuscripts. AS and CdD were involved in drafting the early manuscript and equally contributed to the first draft, which was then expanded and improved by all authors. All authors reviewed and approved the completed manuscript.

\section{Ethics approval and consent to participate} Not applicable.

\section{Consent for publication}

Not applicable.

\section{Competing interests}

The authors declare that they have no competing interests.

\section{Publisher's Note}

Springer Nature remains neutral with regard to jurisdictional claims in published maps and institutional affiliations.

\section{Author details}

'Department of Experimental Medicine, Section of Medical Pathophysiology, Food Science and Endocrinology, Sapienza - University of Rome, Viale Regina Elena 324, 00161 Rome, Italy. ${ }^{2}$ I.O.S.\& COLEMAN Srl, Naples, Italy.

${ }^{3}$ Dipartimento di Medicina Clinica e Chirurgia, Sezione di Endocrinologia, Università "Federico II" di Napoli, Naples, Italy.

Received: 30 October 2017 Accepted: 2 January 2018

Published online: 15 January 2018

\section{References}

1. Sharlip ID, Jarow JP, Belker AM, Lipshultz LI, Sigman M, Thomas AJ, Schlegel PN, Howards SS, Nehra A, Damewood MD, et al. Best practice policies for male infertility. Fertil Steril. 2002;77(5):873-82.

2. Sengupta P, Dutta S, Krajewska-Kulak E. The disappearing sperms: analysis of reports published between 1980 and 2015. Am J Mens Health. 2017;11(4): 1279-304

3. Gaskins AJ, Afeiche MC, Hauser R, Williams PL, Gillman MW, Tanrikut C, Petrozza JC, Chavarro JE. Paternal physical and sedentary activities in relation to semen quality and reproductive outcomes among couples from a fertility center. Hum Reprod. 2014:29(11):2575-82.

4. Eisenberg ML, Kim S, Chen Z, Sundaram R, Schisterman EF, Buck Louis GM The relationship between male BMI and waist circumference on semen quality: data from the LIFE study. Hum Reprod. 2014;29(2):193-200.
5. Barazani Y, Katz BF, Nagler HM, Stember DS. Lifestyle, environment, and male reproductive health. The Urologic clinics of North America. 2014;41(1): 55-66.

6. Moline JM, Golden AL, Bar-Chama N, Smith E, Rauch ME, Chapin RE, Perreault SD, Schrader SM, Suk WA, Landrigan PJ. Exposure to hazardous substances and male reproductive health: a research framework. Environ Health Perspect. 2000;108(9):803-13.

7. Nordkap L, Joensen UN, Blomberg Jensen M, Jorgensen N. Regional differences and temporal trends in male reproductive health disorders: semen quality may be a sensitive marker of environmental exposures. Mol Cell Endocrinol. 2012:355(2):221-30.

8. Gabrielsen JS, Tanrikut C. Chronic exposures and male fertility: the impacts of environment, diet, and drug use on spermatogenesis. Andrology. 2016; 4(4):648-61

9. Cooper TG, Noonan E, von Eckardstein S, Auger J, Baker HW, Behre HM Haugen TB, Kruger T, Wang C, Mbizvo MT, et al. World Health Organization reference values for human semen characteristics. Hum Reprod Update. 2010;16(3):231-45.

10. Tournaye H, Krausz C, Oates RD. Novel concepts in the aetiology of male reproductive impairment. Lancet Diabetes Endocrinol. 2017;5(7):544-53.

11. Johnson SL, Dunleavy J, Gemmell NJ, Nakagawa S. Consistent age-dependent declines in human semen quality: a systematic review and meta-analysis. Ageing Res Rev. 2015;19:22-33.

12. Valenti D, La Vignera S, Condorelli RA, Rago R, Barone N, Vicari E, Calogero AE. Follicle-stimulating hormone treatment in normogonadotropic infertile men. Nat Rev Urol. 2013:10(1):55-62.

13. Lombardo F, Sansone A, Romanelli F, Paoli D, Gandini L, Lenzi A. The role of antioxidant therapy in the treatment of male infertility: an overview. Asian J Androl. 2011;13(5):690-7.

14. Yao DF, Mills JN. Male infertility: lifestyle factors and holistic, complementary, and alternative therapies. Asian J Androl. 2016;18(3):410-8.

15. Prevalence of tobacco use [http://www.who.int/topics/tobacco/en/].

16. Practice Committee of the American Society for Reproductive. M: smoking and infertility: a committee opinion. Fertil Steril. 2012;98(6): $1400-6$

17. Sharma R, Harlev A, Agarwal A, Esteves SC. Cigarette smoking and semen quality: a new meta-analysis examining the effect of the 2010 World Health Organization Laboratory methods for the examination of human semen. Eur Urol. 2016:70(4):635-45.

18. Olsen J, Rachootin P, Schiodt AV, Damsbo N. Tobacco use, alcohol consumption and infertility. Int J Epidemiol. 1983:12(2):179-84.

19. Borgerding $\mathrm{M}$, Klus $\mathrm{H}$. Analysis of complex mixtures-cigarette smoke. Exp Toxicol Pathol. 2005:57(Suppl 1):43-73.

20. Benoff S, Centola GM, Millan C, Napolitano B, Marmar JL, Hurley IR. Increased seminal plasma lead levels adversely affect the fertility potential of sperm in IVF. Hum Reprod. 2003;18(2):374-83.

21. Jurasovic J, Cvitkovic P, Pizent A, Colak B, Telisman S. Semen quality and reproductive endocrine function with regard to blood cadmium in Croatian male subjects. Biometals. 2004;17(6):735-43.

22. Wang X, Zhang J, Xu W, Huang Q, Liu L, Tian M, Xia Y, Zhang W, Shen H. Low-level environmental arsenic exposure correlates with unexplained male infertility risk. Sci Total Environ. 2016:571:307-13.

23. de Angelis C, Galdiero M, Pivonello C, Salzano C, Gianfrilli D, Piscitelli P, Lenzi A, Colao A, Pivonello R. The environment and male reproduction: the effect of cadmium exposure on reproductive functions and its implication in fertility. Reprod Toxicol. 2017:73:105-27.

24. Dai JB, Wang ZX, Qiao ZD. The hazardous effects of tobacco smoking on male fertility. Asian J Androl. 2015:17(6):954-60.

25. Asare-Anane H, Bannison SB, Ofori EK, Ateko RO, Bawah AT, Amanquah SD, Oppong SY, Gandau BB, Ziem JB. Tobacco smoking is associated with decreased semen quality. Reprod Health. 2016;13(1):90.

26. Ramlau-Hansen $\mathrm{CH}$, Thulstrup AM, Aggerholm AS, Jensen MS, Toft G, Bonde JP. Is smoking a risk factor for decreased semen quality? A cross-sectional analysis. Hum Reprod. 2007;22(1):188-96.

27. Kunzle R, Mueller MD, Hanggi W, Birkhauser MH, Drescher $H$, Bersinger NA Semen quality of male smokers and nonsmokers in infertile couples. Fertil Steril. 2003;79(2):287-91.

28. Zavos PM, Correa JR, Karagounis CS, Ahparaki A, Phoroglou C, Hicks CL, Zarmakoupis-Zavos PN. An electron microscope study of the axonemal ultrastructure in human spermatozoa from male smokers and nonsmokers. Fertil Steril. 1998;69(3):430-4 
29. Yeung CH, Tuttelmann F, Bergmann M, Nordhoff V, Vorona E, Cooper TG. Coiled sperm from infertile patients: characteristics, associated factors and biological implication. Hum Reprod. 2009;24(6):1288-95.

30. Zalata AA, Ahmed AH, Allamaneni SS, Comhaire FH, Agarwal A. Relationship between acrosin activity of human spermatozoa and oxidative stress. Asian J Androl. 2004;6(4):313-8.

31. Shrivastava V, Marmor H, Chernyak S, Goldstein M, Feliciano M, Vigodner M. Cigarette smoke affects posttranslational modifications and inhibits capacitation-induced changes in human sperm proteins. Reprod Toxicol. 2014;43:125-9.

32. Taha EA, Ezz-Aldin AM, Sayed SK, Ghandour NM, Mostafa T. Smoking influence on sperm vitality, DNA fragmentation, reactive oxygen species and zinc in oligoasthenoteratozoospermic men with varicocele. Andrologia. 2014;46(6):687-91.

33. Calogero A, Polosa R, Perdichizzi A, Guarino F, La Vignera S, Scarfia A, Fratantonio E, Condorelli R, Bonanno O, Barone N, et al. Cigarette smoke extract immobilizes human spermatozoa and induces sperm apoptosis. Reprod BioMed Online. 2009;19(4):564-71.

34. Sharma R, Biedenharn KR, Fedor JM, Agarwal A. Lifestyle factors and reproductive health: taking control of your fertility. Reproductive biology and endocrinology : RB\&E. 2013;11:66

35. Blanco-Munoz J, Lacasana M, Aguilar-Garduno C. Effect of current tobacco consumption on the male reproductive hormone profile. Sci Total Environ. 2012;426:100-5.

36. Ochedalski T, Lachowicz-Ochedalska A, Dec W, Czechowski B. Examining the effects of tobacco smoking on levels of certain hormones in serum of young men. Ginekol Pol. 1994;65(2):87-93.

37. Lotti F, Corona G, Vitale P, Maseroli E, Rossi M, Fino MG, Maggi M. Current smoking is associated with lower seminal vesicles and ejaculate volume, despite higher testosterone levels, in male subjects of infertile couples. Hum Reprod. 2015;30(3):590-602.

38. Pasqualotto FF, Sobreiro BP, Hallak J, Pasqualotto EB, Lucon AM. Cigarette smoking is related to a decrease in semen volume in a population of fertile men. BJU Int. 2006:97(2):324-6.

39. Esakky P, Hansen DA, Drury AM, Felder P, Cusumano A, Moley KH. Paternal exposure to cigarette smoke condensate leads to reproductive sequelae and developmental abnormalities in the offspring of mice. Reprod Toxicol. 2016:65:283-94

40. Pasqualotto FF, Umezu FM, Salvador M, Borges E, Jr., Sobreiro BP, Pasqualotto EB: Effect of cigarette smoking on antioxidant levels and presence of leukocytospermia in infertile men: a prospective study. Fertil Steril 2008, 90(2):278-283.

41. Abdul-Ghani R, Qazzaz M, Dabdoub N, Muhammad R, Abdul-Ghani AS. Studies on cigarette smoke induced oxidative DNA damage and reduced spermatogenesis in rats. J Environ Biol. 2014;35(5):943-7.

42. La Maestra S, De Flora S, Micale RT. Effect of cigarette smoke on DNA damage, oxidative stress, and morphological alterations in mouse testis and spermatozoa. Int J Hyg Environ Health. 2015;218(1):117-22.

43. Kim KH, Joo KJ, Park HJ, Kwon CH, Jang MH, Kim CJ. Nicotine induces apoptosis in TM3 mouse Leydig cells. Fertil Steril. 2005;83(Suppl 1):1093-9.

44. Yeung K, Janosch P, McFerran B, Rose DW, Mischak H, Sedivy JM, Kolch W. Mechanism of suppression of the Raf/MEK/extracellular signal-regulated kinase pathway by the raf kinase inhibitor protein. Mol Cell Biol. 2000;20(9): 3079-85.

45. Aprioku JS, Ugwu TC. Tobacco smoke exposure induces irreversible alteration of testicular function in prepubertal rats. J Basic Clin Physiol Pharmacol. 2016;27(6):577-84.

46. Oyeyipo IP, Raji Y, Bolarinwa AF. Nicotine alters male reproductive hormones in male albino rats: the role of cessation. J Hum Reprod Sci. 2013; 6(1):40-4.

47. Harte $C B$, Meston CM. Association between smoking cessation and sexual health in men. BJU Int. 2012;109(6):888-96.

48. Oyeyipo IP, Raji Y, Emikpe BO, Bolarinwa AF. Effects of nicotine on sperm characteristics and fertility profile in adult male rats: a possible role of cessation. J Reprod Infertil. 2011;12(3):201-7.

49. Shenker NS, Ueland PM, Polidoro S, van Veldhoven K, Ricceri F, Brown R, Flanagan JM, Vineis P. DNA methylation as a long-term biomarker of exposure to tobacco smoke. Epidemiology. 2013;24(5):712-6.

50. Cui $X$, Jing $X$, Wu $X$, Wang $Z$, Li Q. Potential effect of smoking on semen quality through DNA damage and the downregulation of Chk1 in sperm. Mol Med Rep. 2016;14(1):753-61.
51. Harlev A, Agarwal A, Gunes SO, Shetty A, du Plessis SS. Smoking and male infertility: an evidence-based review. The world journal of men's health. 2015;33(3):143-60

52. Agarwal A, Majzoub A, Esteves SC, Ko E, Ramasamy R, Zini A. Clinical utility of sperm DNA fragmentation testing: practice recommendations based on clinical scenarios. Transl Androl Urol. 2016;5(6):935-50.

53. Loft $\mathrm{S}$, Kold-Jensen T, Hjollund NH, Giwercman A, Gyllemborg J, Ernst E, Olsen J, Scheike T, Poulsen HE, Bonde JP, Oxidative DNA. Damage in human sperm influences time to pregnancy. Hum Reprod. 2003;18(6):1265-72.

54. Sapra KJ, Barr DB, Maisog JM, Sundaram R, Buck Louis GM. Time-topregnancy associated with Couples' use of tobacco products. Nicotine Tob Res. 2016;18(11):2154-61.

55. Ghaffari MA, Rostami M. The effect of cigarette smoking on human sperm creatine kinase activity: as an ATP buffering system in sperm. Int J Fertil Steril. 2013:6(4):258-65.

56. Sofikitis N, Takenaka M, Kanakas N, Papadopoulos H, Yamamoto Y, Drakakis P. Miyagawa I. Effects of cotinine on sperm motility, membrane function, and fertilizing capacity in vitro. Urol Res. 2000;28(6):370-5.

57. Oyeyipo IP, Maartens PJ, du Plessis SS. In vitro effects of nicotine on human spermatozoa. Andrologia. 2014;46(8):887-92.

58. Kucheria K, Saxena R, Mohan D. Semen analysis in alcohol dependence syndrome. Andrologia. 1985;17(6):558-63.

59. Pajarinen JT, Karhunen PJ. Spermatogenic arrest and 'Sertoli cell-only' syndrome-common alcohol-induced disorders of the human testis. Int J Androl. 1994;17(6):292-9.

60. Muthusami KR, Chinnaswamy P. Effect of chronic alcoholism on male fertility hormones and semen quality. Fertil Steril. 2005;84(4):919-24.

61. Li Y, Lin H, Li Y, Cao J. Association between socio-psycho-behavioral factors and male semen quality: systematic review and meta-analyses. Fertil Steril. 2011;95(1):116-23.

62. Jensen TK, Gottschau M, Madsen JO, Andersson AM, Lassen TH, Skakkebaek NE, Swan SH, Priskorn L, Juul A, Jorgensen N. Habitual alcohol consumption associated with reduced semen quality and changes in reproductive hormones; a cross-sectional study among 1221 young Danish men. BM Open. 2014;4(9):e005462

63. Hansen ML, Thulstrup AM, Bonde JP, Olsen J, Hakonsen LB, Ramlau-Hansen $\mathrm{CH}$. Does last week's alcohol intake affect semen quality or reproductive hormones? A cross-sectional study among healthy young Danish men. Reprod Toxicol. 2012;34(3):457-62.

64. Condorelli RA, Calogero AE, Vicari E, La Vignera S. Chronic consumption of alcohol and sperm parameters: our experience and the main evidences. Andrologia. 2015;47(4):368-79.

65. Hassan MA, Killick SR. Negative lifestyle is associated with a significant reduction in fecundity. Fertil Steril. 2004;81(2):384-92.

66. Close CE, Roberts PL, Berger RE. Cigarettes, alcohol and marijuana are related to pyospermia in infertile men. J Urol. 1990;144(4):900-3.

67. Ramlau-Hansen CH, Toft G, Jensen MS, Strandberg-Larsen K, Hansen ML, Olsen J. Maternal alcohol consumption during pregnancy and semen quality in the male offspring: two decades of follow-up. Hum Reprod. 2010; 25(9):2340-5.

68. Yin D, Mufson RA, Wang R, Shi Y. Fas-mediated cell death promoted by opioids. Nature. 1999;397(6716):218

69. Gianoulakis $C$. Characterization of the effects of acute ethanol administration on the release of beta-endorphin peptides by the rat hypothalamus. Eur J Pharmacol. 1990;180(1):21-9.

70. Talebi AR, Sarcheshmeh AA, Khalili MA, Tabibnejad N. Effects of ethanol consumption on chromatin condensation and DNA integrity of epididymal spermatozoa in rat. Alcohol. 2011;45(4):403-9.

71. Jana K, Jana N, De DK, Guha SK. Ethanol induces mouse spermatogenic cell apoptosis in vivo through over-expression of Fas/Fas-L, p53, and caspase-3 along with cytochrome $\mathrm{c}$ translocation and glutathione depletion. Mol Reprod Dev. 2010;77(9):820-33.

72. Gaspari L, Chang SS, Santella RM, Garte S, Pedotti P, Taioli E. Polycyclic aromatic hydrocarbon-DNA adducts in human sperm as a marker of DNA damage and infertility. Mutat Res. 2003;535(2):155-60.

73. Rossi BV, Berry KF, Hornstein MD, Cramer DW, Ehrlich S, Missmer SA. Effect of alcohol consumption on in vitro fertilization. Obstet Gynecol. 2011;117(1): 136-42.

74. Horak S, Polanska J, Widlak P. Bulky DNA adducts in human sperm: relationship with fertility, semen quality, smoking, and environmental factors. Mutat Res. 2003;537(1):53-65. 
75. Pajarinen J, Savolainen V, Perola M, Penttila A, Karhunen PJ. Polymorphism in the cytochrome P450 2E1 gene and alcohol-induced disorders of human spermatogenesis. Int J Androl. 1996;19(5):314-22.

76. Fronczak CM, Kim ED, Barqawi $A B$. The insults of illicit drug use on male fertility. J Androl. 2012;33(4):515-28.

77. du Plessis SS, Agarwal A, Syriac A. Marijuana, phytocannabinoids, the endocannabinoid system, and male fertility. J Assist Reprod Genet. 2015; 32(11):1575-88.

78. Kolodny RC, Masters WH, Kolodner RM, Toro G. Depression of plasma testosterone levels after chronic intensive marihuana use. N Engl J Med. 1974;290(16):872-4.

79. Friedrich G, Nepita W, Andre T. Serum testosterone concentrations in cannabis and opiate users. Beitr Gerichtl Med. 1990;48:57-66.

80. Mendelson JH, Kuehnle J, Ellingboe J, Babor TF. Plasma testosterone levels before, during and after chronic marihuana smoking. N Engl J Med. 1974; 291(20):1051-5.

81. Cone EJ, Johnson RE, Moore JD, Roache JD. Acute effects of smoking marijuana on hormones, subjective effects and performance in male human subjects. Pharmacol Biochem Behav. 1986;24(6):1749-54.

82. Gundersen TD, Jorgensen N, Andersson AM, Bang AK, Nordkap L, Skakkebaek NE, Priskorn L, Juul A, Jensen TK. Association between use of marijuana and male reproductive hormones and semen quality: a study among 1,215 healthy young men. Am J Epidemiol. 2015;182(6):473-81.

83. Hembree WC 3rd, Nahas GG, Zeidenberg P, Huang HF. Changes in human spermatozoa associated with high dose marihuana smoking. Adv Biosci. 1978;22-23:429-39.

84. Singer R, Ben-Bassat M, Malik Z, Sagiv M, Ravid A, Shohat B, Livni E, Mamon T, Segenreich E, Servadio C. Oligozoospermia, asthenozoospermia, and sperm abnormalities in ex-addict to heroin, morphine, and hashish. Arch Androl. 1986;16(2):167-74.

85. Pacey AA, Povey AC, Clyma JA, McNamee R, Moore HD, Baillie H, Cherry NM, Participating Centres of Chaps-UK. Modifiable and non-modifiable risk factors for poor sperm morphology. Hum Reprod. 2014;29(8):1629-36.

86. Bracken MB, Eskenazi B, Sachse K, McSharry JE, Hellenbrand K, Leo-Summers L. Association of cocaine use with sperm concentration, motility, and morphology. Fertil Steril. 1990;53(2):315-22.

87. Samplaski MK, Bachir BG, Lo KC, Grober ED, Lau S, Jarvi KA. Cocaine use in the infertile male population: a marker for conditions resulting in subfertility. Current urology. 2015;8(1):38-42.

88. Vuong C, Van Uum SH, O'Dell LE, Lutfy K, Friedman TC. The effects of opioids and opioid analogs on animal and human endocrine systems. Endocr Rev. 2010;31(1):98-132.

89. Safarinejad MR, Asgari SA, Farshi A, Ghaedi G, Kolahi AA, Iravani S, Khoshdel AR. The effects of opiate consumption on serum reproductive hormone levels, sperm parameters, seminal plasma antioxidant capacity and sperm DNA integrity. Reprod Toxicol. 2013;36:18-23.

90. Schuel H, Chang MC, Berkery D, Schuel R, Zimmerman AM, Zimmerman S. Cannabinoids inhibit fertilization in sea urchins by reducing the fertilizing capacity of sperm. Pharmacol Biochem Behav. 1991;40(3): 609-15.

91. Zimmerman AM, Zimmerman S, Raj AY. Effects of cannabinoids on spermatogenesis in mice. Adv Biosci. 1978;22-23:407-18.

92. Wenger $T$, Rettori $V$, Snyder GD, Dalterio S, McCann SM. Effects of delta-9-tetrahydrocannabinol on the hypothalamic-pituitary control of luteinizing hormone and follicle-stimulating hormone secretion in adult male rats. Neuroendocrinology. 1987;46(6):488-93.

93. Smith C, Moore C, Besch N, Besch P. Effect of marihuana (delta-9 tetrahydrocannabinol) on secretion of sex-hormones in mature male rhesus-monkey. In: Clinical Chemistry: 1976: AMER ASSOC CLINICAL CHEMISTRY 2101 L STREET NW, SUITE 202, WASHINGTON, DC 20037-1526; 1976. p. 1184

94. Banerjee A, Singh A, Srivastava P, Turner H, Krishna A. Effects of chronic bhang (cannabis) administration on the reproductive system of male mice. Birth Defects Res B Dev Reprod Toxicol. 2011;92(3):195-205.

95. Chakravarty I, Ghosh JJ. Influence of cannabis and delta-9-tetrahydrocannabinol on the biochemistry of the male reproductive organs. Biochem Pharmacol. 1981;30(4):273-6.

96. Li H, George VK, Crawford SC, Dhabuwala CB. Effect of cocaine on testicular blood flow in rats: evaluation by percutaneous injection of xenon-133. J Environ Pathol Toxicol Oncol. 1999;18(1):73-7.
97. George VK, Li H, Teloken C, Grignon DJ, Lawrence WD, Dhabuwala CB. Effects of long-term cocaine exposure on spermatogenesis and fertility in peripubertal male rats. J Urol. 1996;155(1):327-31.

98. Li H, Jiang Y, Rajpurkar A, Tefilli MV, Dunbar JC, Dhabuwala CB. Lipid peroxidation and antioxidant activities in rat testis after chronic cocaine administration. Urology. 1999;54(5):925-8.

99. Barenys M, Gomez-Catalan J, Camps L, Teixido E, de Lapuente J, GonzalezLinares J, Serret J, Borras M, Rodamilans M, Llobet JM. MDMA (ecstasy) delays pubertal development and alters sperm quality after developmental exposure in the rat. Toxicol Lett. 2010;197(2):135-42.

100. Abdellatief RB, Elgamal DA, Mohamed EE. Effects of chronic tramadol administration on testicular tissue in rats: an experimental study. Andrologia. 2015:47(6):674-9.

101. Ahmadnia H, Akhavan Rezayat A, Hoseyni M, Sharifi N, Khajedalooee M, Akhavan Rezayat A. Short-period influence of chronic morphine exposure on serum levels of sexual hormones and spermatogenesis in rats. Nephrourol Mon. 2016;8(4):e38052.

102. Whan LB, West MC, McClure N, Lewis SE. Effects of delta-9tetrahydrocannabinol, the primary psychoactive cannabinoid in marijuana, on human sperm function in vitro. Fertil Steril. 2006;85(3):653-60.

103. Amoako AA, Marczylo TH, Marczylo EL, Elson J, Willets JM, Taylor AH, Konje JC. Anandamide modulates human sperm motility: implications for men with asthenozoospermia and oligoasthenoteratozoospermia. Hum Reprod. 2013;28(8):2058-66.

104. Morgan DJ, Muller CH, Murataeva NA, Davis BJ, Mackie K. Delta9Tetrahydrocannabinol (Delta9-THC) attenuates mouse sperm motility and male fecundity. Br J Pharmacol. 2012;165(8):2575-83.

\section{Submit your next manuscript to BioMed Central and we will help you at every step:}

- We accept pre-submission inquiries

- Our selector tool helps you to find the most relevant journal

- We provide round the clock customer support

- Convenient online submission

- Thorough peer review

- Inclusion in PubMed and all major indexing services

- Maximum visibility for your research

Submit your manuscript at www.biomedcentral.com/submit
) Biomed Central 